Chirurgia (2021) 116: 554-567

No. 5, September - October

Copyright@ Celsius

http://dx.doi.org/10.21614/chirurgia.116.5.554

\title{
Venous Resections in Pancreatic Head Carcinoma - 15 Years Experience with Survival and Prognostic Factor Analysis
}

\author{
Nikola Vladov, Tsvetan Trichkov*, Vassil Mihaylov, Ivelin Takorov, Tsonka Lukanova, Radoslav Kostadinov, \\ Stefan Marvakov
}

HPB Surgery and Transplantology, Military Medical Academy, Sofia, Bulgaria

\author{
${ }^{*}$ Corresponding author: \\ Tsvetan Trichkov, M.D. \\ Clinic of HPB Surgery and \\ Transplantology \\ Military Medical Academy, Sofia \\ Bulgaria \\ Sv. Georgi Sofiyski Street No.3, \\ floor 14, 1606 Sofia, Bulgaria \\ E-mail: cvetantrichkov@gmail.com \\ Abbreviations: \\ PDR: pancreatoduodenal resection, \\ VR: briefly from pancreatoduodenal \\ venous resection, \\ PP: palliative procedure, \\ PDAC: pancreatic ductal adenocarcinoma, \\ ChT: chemotherapy, \\ ISGPS: International Study Group of \\ Pancreatic Surgery, \\ NCCN: National Comprehensive Cancer \\ Network, \\ SMV: superior mesenteric vein, \\ SMA: superior mesenteric artery, \\ PMVA: portomesenteric venous axis, \\ BRPC: borderline resectable pancreatic \\ cancer, \\ POPF: postoperative pancreatic fistula, \\ POBF: postoperative biliary fistula, \\ AJCC: American Joint Committee of \\ Cancer
}

\section{Rezumat}

Rezecții venoase în carcinomul de cap de pancreas - 15 ani de experiență în analiza factorilor de supraviețire și prognostic

Context: Prezentăm o analiză comparativă a supraviețuirii, a complicațiilor şi a factorilor de risc major la pacienții cu intervenție chirurgicală pentru carcinomul de cap de pancreas.

Metode: Acesta este un studiu retrospectiv, unicentric, care evalueză caracteristicile clinice, chirurgicale şi anatomo-patologice a 467 de pacienti cu interventii chirurgicale radicale pentru carcinomul de cap de pancreas, în perioada septembrie 2004 octombrie 2019. Studiul include 88 de pacienți (18.8\%) cu rezecții venoase pentru adenocarcinom pancreatic la limita rezecabilității. Rezultate: Ratele de supraviețuire estimate au fost semnificativ diferite din punct de vedere statistic, cu 19.3 luni în rezectiile venoase pancreatico-duodenale (RV) şi 26.9 luni în rezectiile pancreatico-duodenale $(\mathrm{RPD})$, respectiv $(\mathrm{p}=0.047)$. Pe de altă parte, ratele de supraviețire la unu, trei şi cinci ani de $46.6 \%, 17.6 \%$ şi $8.3 \%$ în RV şi $53.6 \%, 20.8 \%, 14.9 \%$ în RPD nu au prezentat diferențe semnificative statistic $(\mathrm{p}=0.13,0.5$ şi 0.11 respectiv). Ratele de supraviețire în RPD, RV şi procedurile paliative (PP) între cele trei grupuri diferă semnificativ statistic $(p<0.05)$. Complicațiile postoperatorii relevante clinic în rezectiile venoase (13.6\%) față de 14.8\% în RPD nu au prezentat diferențe semnificative statistic $(p=0.77)$. Hemoragia postoperatorie şi reintervenția $(p<0.05)$ sunt factori de prognostic independenți pentru rezultate mai slabe. $\mathrm{Nu}$ a existat o relație semnificativă statistic între supraviețuire şi prezența invaziei vasculare $(p=0.581)$. 
Concluzii: Atunci când sunt efectuate de chirurgi experimentați în centre specializate cu volum mare, rezecțiile pancreatico-duodenale combinate cu rezecția venoasă şi reconstrucția sunt proceduri chirurgicale fiabile şi sigure.

Cuvinte cheie: adenocarcinom ductal pancreatic, rezecție pancreaticoduodenală, rezecție venoasă

\begin{abstract}
Background:We present a comparative analysis of survival, complications and major risk factors in patients who underwent surgery for pancreatic head carcinoma.

Methods: This is a single-centre retrospective study aimed to evaluate clinical, surgical and pathoanatomical features of 467 patients who underwent radical surgery for pancreatic head carcinoma between September 2004 and October 2019. The series includes 88 patients (18.8\%) with venous resections for borderline resectable pancreatic adenocarcinoma.

Results: The estimated median survival rates were statistically significant with 19.3 months in pancreatoduodenal venous resections (VR) and 26.9 months in pancreatoduodenal resections (PDR), respectively $(\mathrm{p}=0.047)$. On the other hand, one, three, and five-year survival rates of $46.6 \%, 17.6 \%$ and $8.3 \%$ in VR, and $53.6 \%, 20.8 \%, 14.9 \%$ in PDR were not statistically significant ( $\mathrm{p}=0.13,0.5$ and 0.11 respectively). Survival rates comparison in PDR, VR, and palliative procedures (PP) between the three groups showed statistical significance $(p<0.05)$. The clinically relevant postoperative complications in venous resections $(13.6 \%)$ vs. $14.8 \%$ in PDR were not statistically significant $(p=0.77)$. Postoperative bleeding and reoperation $(p<0.05)$ are independent prognostic factors for worse outcomes. There was no statistically significant relationship between survival and presence of vascular invasion $(\mathrm{p}=0.581)$.

Conclusions: When performed by experienced surgeons at specialized high-volume centres, pancreatoduodenal resections combined with venous resection and reconstruction are reliable and safe surgical procedures.
\end{abstract}

Key words: pancreatic ductal adenocarcinoma, pancreatoduodenal resection, venous resection

\section{Introduction}

Over the last decades pancreatic ductal adenocarcinoma (PDAC) has established itself as one of the most lethal digestive tract tumours. It constitutes $90 \%$ of all pancreatic neoplasm, with 5-year survival rate of only $7-8 \%$ (1). PDAC is the fourth leading cause of cancer-related mortality in industrially developed countries and expected to become the second leading cause of cancer-related death by the end of 2030 (2). At present the only curative option for PDAC patients is radical surgical resection (3). Unfortunately, only $15 \%$ to $20 \%$ of patients qualify for upfront surgery $(4,5)$, as over $50 \%$ of them present with distant metastases and 35\% with locally advanced disease at the time of diagnosis $(6,7)$.

Preoperative disease staging is essential for selection of patients eligible for surgery (8). The conventional approach in resectable disease is performance of surgery followed by adjuvant chemotherapy (ChT). The neoadjuvant approach in the treatment of PDAC is increasingly being recommended over recent years. Three grades of resectability can be defined for localized PDAC which are termed as resectable, borderline resectable, and irresectable (5). Resectable tumours are characterized by a clean connective-tissue margin along the superior mesenteric artery (SMA). Borderline resectability is defined as 
compression or occlusion of the portomesenteric venous axis (PMVA), with a technical possibility of reconstruction on the proximal and distal margin of the veins. Furthermore, tumours with abutment $\left(<180^{\circ}\right)$ of the SMA, or at the hepatic artery, are also regarded as borderline resectable. Irresectability is defined as an encasement of the SMA $\left(>180^{\circ}\right)$ or no technical possibility for venous resection and reconstruction. Tumour involvement of major blood vessels is present in approximately $50 \%$ of the patients (9). With the improvement in modern imaging and surgical techniques the number of patients diagnosed with borderline resectable pancreatic cancer (BRPC) is growing $(5,10)$. Nevertheless, the borderline concept is not well defined yet, with a lot of differences in international definitions, com- $^{-}$ plicating its interpretation. In some highly specialized centres VR is performed in up to $20-25 \%$ of patients $(3,11-13)$. The main aim of the procedure is achievement of a clear resection margin. This aggressive surgical approach of vascular resection and reconstruction is the only chance for longer survival of patients with borderline resectable pancreatic cancer $(3,14)$.

There are four known techniques of vein reconstruction, namely: tangential resection with suture (Fig. 1); tangential resection with patch angioplasty (Fig. 2); segmental resection with end-to-end anastomosis (Fig. 3) and segmental resection with graft (Fig. 4) (15-17).

The grafts can be either autologous (from renal or saphenous vein) (18) or synthetic vascular prosthesis for venous segment "bridging". However, the use of synthetic grafts is associated with risks of complications as infection or anastomotic leakage (19).

situation of a synthetic graft in combination with a postoperative pancreatic fistula (POPF) should be regarded as a high-risk constellation for postoperative haemorrhage or difficult to treat long-lasting graft infection. Direct venous reconstructions, without use of patch or graft, have demonstrated fewer thrombotic complications (20), while the use of synthetic prostheses is associated

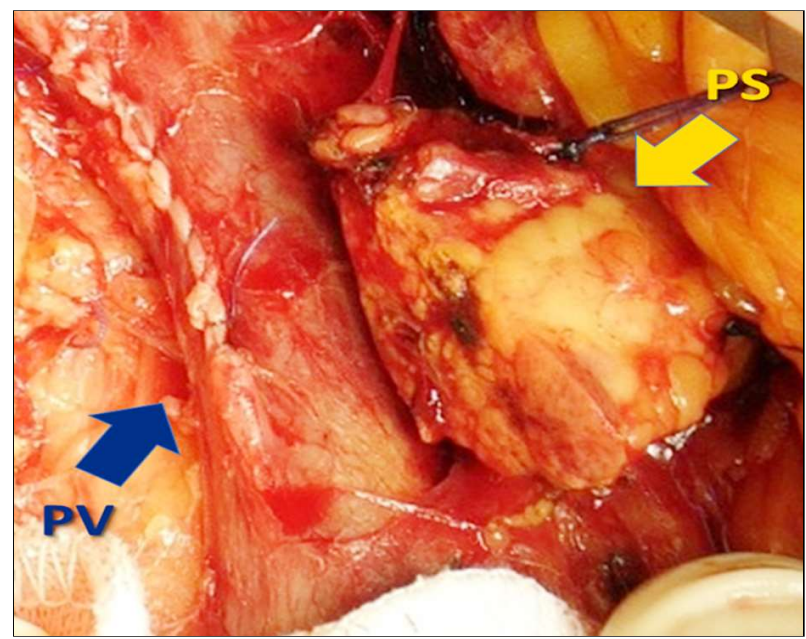

Figure 1. Tangential resection of the portal vein PV - portal vein; PS - pancreatic stump

with four-fold higher risk of early thrombosis and worse survival outcome (21).

To most surgeons, arterial invasion is an absolute contraindication for surgical resection (22-25), while according to others it should be performed only in strictly selected cases after careful benefit-risk assessment (19,26-30). Artery resection as a routine procedure is not recommended by the ISGPS guidelines. The „artery-first" approach is a useful procedure for assessment of suspected retroperitoneal involvement of SMA (31).

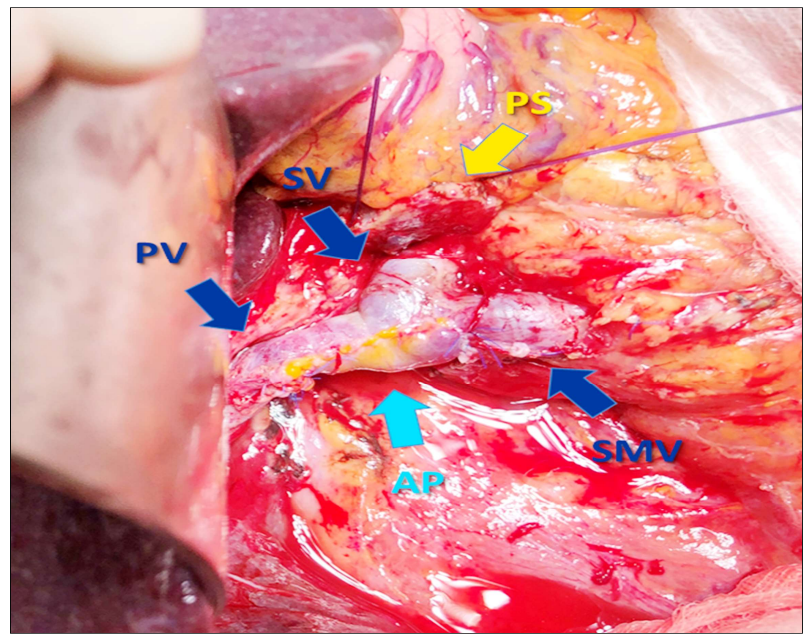

Figure 2. Tangential resection and reconstruction with peritoneal patch from the falciform ligament

AP - autologous patch (falciform ligament); PV - portal vein; SMV - superior mesenteric vein; SV - splenic vein; PS - pancreatic stump 


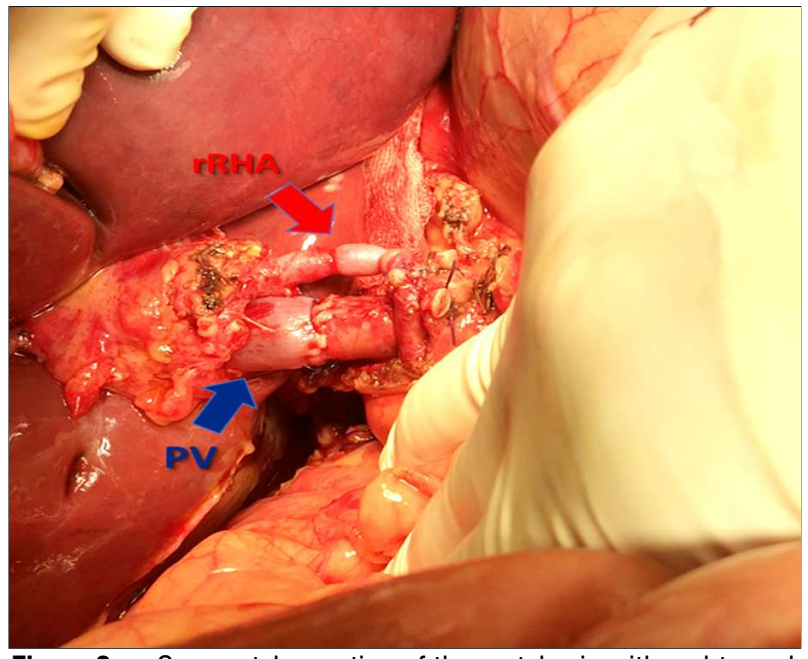

Figure 3. Segmental resection of the portal vein with end-to-end anastomosis, as well as reconstruction of replaced right hepatic artery from SMA

PV - portal vein; rRHA - replaced right hepatic artery

\section{Material and Method}

This is a single-centre retrospective study evaluating clinical, surgical and pathoanatomical features of 467 patients with performed pancreatoduodenal resection during the period between September 2004 and October 2019. The series includes only patients who underwent surgery for pancreatic head adenocarcinoma and excludes all benign diseases. To compare survival, a representative group of 120 randomly selected patients who underwent palliative procedures (exploration or bypass anastomoses) was included. All patients underwent contrast-enhanced $\mathrm{CT}$ as a routine preoperative work-up. Magnetic resonance imaging, endoscopic ultrasound scan, and laparoscopy were performed on an individual basis based on the multidisciplinary team discussion. The final operative decision lay with the surgeon at the procedure. The preferred operative approach was bilateral subcostal laparotomy. Jejunum was exclusively used for the anastomosis to the pancreas (duct to seromuscular type, two layers) and for bile reconstruction successively. In 88 patients (18.8\%) was performed venous resection for borderline resectable pancreatic adenocarcinoma. The conducted comprehensive statistical analysis included various factors and parameters as postoperative complications, perioperative mortality (30 days), shortand long-term survival, as well as different histological characteristics. Categorical data were compared using $\chi^{2}$ test and confidence interval (95\%). P-value $<0.05$ was adopted as statistically significant. For statistical analysis of the parameters was used SPSS $^{\circledR}$ Statistics, Version 26.0 of IBM $^{\circledR}$.
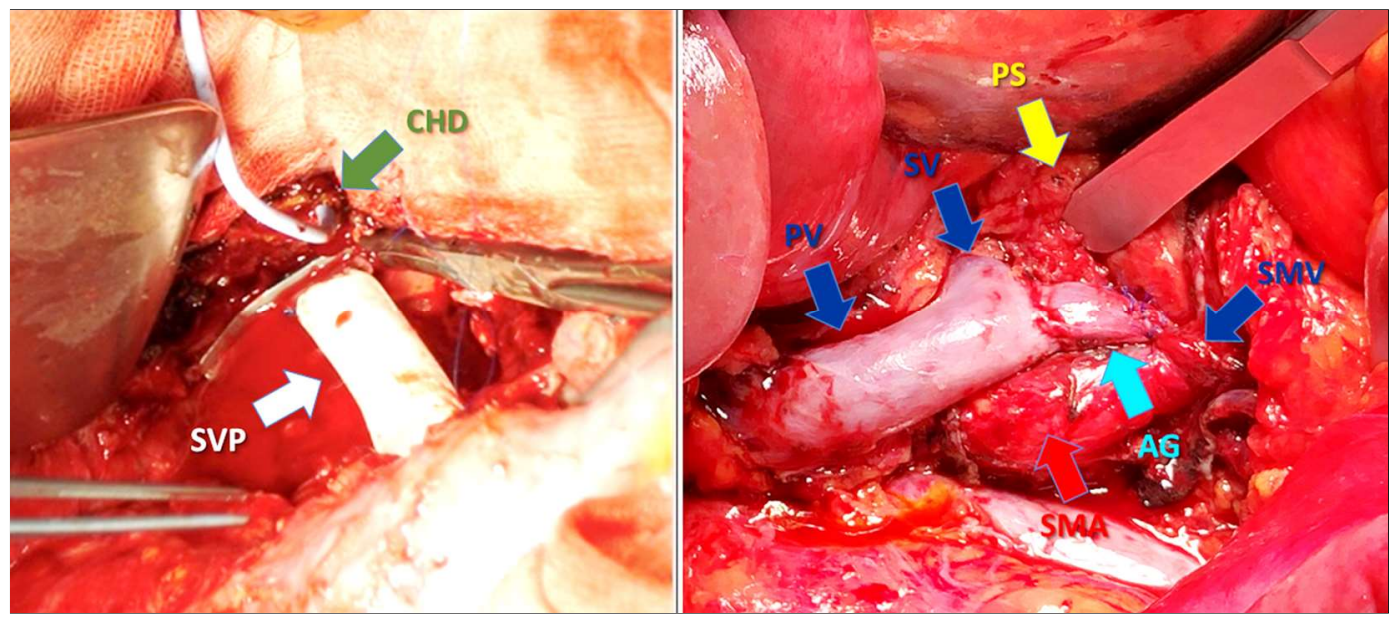

Figure 4. Segmental resections and reconstructions with grafts: Left - reconstruction of the portal vein with synthetic prosthesis (PTFE); Right - autologous reconstruction of the SMV (Left renal vein) CHD - common hepatic duct; SVP - synthetic vascular prosthesis; AG - autologous graft; PV - portal vein; SMV - superior mesenteric vein; SV - splenic vein; SMA - superior mesenteric artery; PS - pancreatic stump 


\section{Results}

In Tables 1, 2 and 3 are presented clinical, surgical and pathoanatomical parameters, as well as a comparison of complications between the two target groups. The differences in some values are clearly statistically significant, while others are with borderline significance. The median survival rates of 19.3 months in 88 VR patients and 26.9 months in patients with PDR were statistically significant $(\mathrm{p}=0.047$, Table 1). On the other hand, 1-, 3and 5-year survival rates of $46.6 \%, 17.6 \%$ and $8.3 \%$ in VR and $53.6 \%, 20.8 \%$ and $14.9 \%$ in PDR were statistically insignificant $(p=0.13$, 0.5 and 0.11 respectively, Table 1). KaplanMaier survival comparison in PDR (26.9 mo), VR (19.3 mo) and PP (8.4 mo) showed statistically significant differences between all three groups $(\mathrm{p}<0.05)$. The observed perioperative 30-day mortality rate of $12.5 \%$ in VR was markedly significant compared to $3.2 \%$ in standard procedures $(\mathrm{p}<0.05$, Table 1). The data show, that the incidence of clinically relevant postoperative complications graded in accordance with the Clavien-Dindo classifi- cation (III+IV) was not statistically significant - $13.6 \%$ in VR vs. $14.8 \%$ in PDR $(p=0.77$, Table 2). On the other hand, the rate of certain complications was statistically significant. Besides being significant in both patient groups, postoperative bleeding $(p<0.05)$ and reoperation $(p<0.05)$ are independent prognostic factors for worse outcomes. $44.3 \%$ of vascular resections required intra- or postoperative blood transfusions compared to only $19.8 \%$ in the standard procedures group $(\mathrm{p}<0.05$, Table 1). Compared to PDR, a significantly higher percentage of G3-carcinomas $(p=0.045)$, as well as more frequent achievement of R0-resections ( $p=0.039$ ), was typical in VR (Table 2). In 10 cases (11.4\%) in VR and 73 (19.3 \%) in PDR it was not possible to identify the resection margins (R) due to learning curve of the pathologist or inaccuracy in the processing of the specimens (Table 3). The same goes to vascular and perineural invasion status. For this reason, these cases are excluded from the statistical survival comparison. No statistically significant relationship was found between survival and vascular invasion status in the VR group $(\mathrm{p}=0.58)$.

Table 1. Clinical parameters

\begin{tabular}{|c|c|c|c|c|c|}
\hline Parameters & PDR & VR & $\mathbf{P}$ & $95 \% \mathrm{CI}$ & $\chi^{2}$ test \\
\hline \multicolumn{6}{|l|}{ Gender } \\
\hline Male & $246(64.9 \%)$ & $47(53.4 \%)$ & 0.045 & 0.295 to 22.836 & 4.031 \\
\hline Female & $133(35.1 \%)$ & $41(46.6 \%)$ & 0.045 & 0.295 to 22.836 & 4.031 \\
\hline Age (average) & 59.5 & 60.5 & 0.362 & -1.155 to 3.155 & - \\
\hline Jaundice & $331(82.6 \%)$ & $63(71.6 \%)$ & 0.020 & 1.669 to 21.750 & 5.499 \\
\hline Pain & $121(31.9 \%)$ & $42(47.7 \%)$ & 0.005 & 4.577 to 27.047 & 7.833 \\
\hline Previous jaundice operations & $35(9.2 \%)$ & $7(8.0 \%)$ & 0.723 & -6.783 to 6.455 & 0.126 \\
\hline Bile duct stenting & $245(64.6 \%)$ & $52(59.1 \%)$ & 0.335 & -5.369 to 16.930 & 0.931 \\
\hline \multicolumn{6}{|l|}{ Type of operation } \\
\hline PPPD & $306(80.7 \%)$ & $57(64.8 \%)$ & 0.001 & 5.785 to 26.930 & 10.399 \\
\hline Whipple procedure & $69(18.2 \%)$ & $23(26.1 \%)$ & 0.094 & -1.168 to 18.549 & 2.813 \\
\hline Total pancreatectomy & $4(1.1 \%)$ & $8(9.1 \%)$ & 0.000 & 3.288 to 15.865 & 17.960 \\
\hline Blood transfusion & $75(19.8 \%)$ & $39(44.3 \%)$ & 0.000 & 13.682 to 35.539 & 23.179 \\
\hline Average hospital stays (days) & 16.6 & 17.1 & 0.576 & -1.257 to 2.257 & - \\
\hline Average survival (months) & 26.9 & 19.3 & 0.047 & -15.094 to -0.106 & - \\
\hline \multicolumn{6}{|l|}{ Annual survival } \\
\hline 1-year & $53.6 \%$ & $46.6 \%$ & 0.128 & -2.548 to 20.111 & 2.312 \\
\hline 3-years & $20.8 \%$ & $17.6 \%$ & 0.501 & -6.804 to 11.074 & 0.453 \\
\hline 5-years & $14.9 \%$ & $8.3 \%$ & 0.105 & -1.705 to 12.328 & 2.633 \\
\hline 30-day mortality & $12(3.2 \%)$ & $11(12.5 \%)$ & 0.000 & 3.456 to 17.919 & 13.094 \\
\hline
\end{tabular}

PDR - pancreatoduodenal resections; VR - vascular resections; P - p-value; $95 \% \mathrm{Cl}$ - Confidence interval (95\%); $\chi^{2}$ test - Chi-squared test 
Table 2. Surgical complications

\begin{tabular}{llllll}
\hline Parameters & PDR & VR & P & 95\% Cl & $\chi^{2}$ test \\
\hline Dindo-Clavien IIIA/IIIB/IV & $56(14.8 \%)$ & $12(13.6 \%)$ & 0.774 & -8.074 to 8.082 & 0.082 \\
\hline Bleeding & $47(12.4 \%)$ & $19(21.6 \%)$ & 0.026 & 1.005 to 19.325 & 4.970 \\
\hline Reoperation & $48(12.7 \%)$ & $20(22.7 \%)$ & 0.017 & 5.721 to 20.229 & 5.721 \\
\hline POPF & $45(11.9 \%)$ & $6(6.8 \%)$ & 0.168 & -2.715 to 10.260 & 1.903 \\
\hline POBF & $17(4.5 \%)$ & $4(4.5 \%)$ & 1.000 & -3.768 to 6.760 & 0.000 \\
\hline Sepsis & $10(2.6 \%)$ & $8(9.1 \%)$ & 0.004 & 1.594 to 14.426 & 8.185 \\
\hline DGE & $36(9.5 \%)$ & $5(5.7 \%)$ & 0.257 & -3.600 to 8.475 & 1.284 \\
\hline Abscess & $25(6.6 \%)$ & $9(10.2 \%)$ & 0.242 & -1.993 to 11.940 & 0.119 \\
\hline
\end{tabular}

PDR - pancreatoduodenal resections; VR - vascular resections; P - p-value; $95 \% \mathrm{Cl}$ - Confidence interval $(95 \%) ; \chi^{2}$ test - Chi-squared test

Table 3. Pathological parameters

\begin{tabular}{llllll}
\hline Parameters & PDR & VR & P & 95\% Cl & $\chi^{2}$ test \\
\hline Average tumour size (cm) & 3.08 & 3.26 & 0.193 & -0.091 to 0.451 & - \\
\hline $\begin{array}{l}\text { Perineural invasion } \\
\text { Pn+ }\end{array}$ & $215(56.7 \%)$ & $57(64.8 \%)$ & 0.166 & -3.401 to 18.558 & 1.922 \\
Pn- & $71(18.7 \%)$ & $10(11.4 \%)$ & 0.104 & -1.760 to 13.914 & 2.651 \\
Pnx & $93(24.5 \%)$ & $21(23.9 \%)$ & 0.906 & -10.083 to 9.554 & 0.014 \\
\hline Degree of differentiation & & & & & \\
G1 & $62(16.4 \%)$ & $7(7.95 \%)$ & 0.045 & 0.162 to 14.183 & 4.034 \\
G2 & $231(60.9 \%)$ & $52(59.1 \%)$ & 0.756 & -9.096 to 13.285 & 0.097 \\
G3 & $86(22.7 \%)$ & $29(32.95 \%)$ & 0.045 & 0.263 to 21.324 & 4.033 \\
\hline Lymph nodes & & & & & \\
N+ & $187(49.3 \%)$ & $40(45.5 \%)$ & 0.521 & -7.717 to 14.985 & 0.412 \\
N- & $146(38.5 \%)$ & $32(36.4 \%)$ & 0.715 & -9.361 to 12.644 & 0.133 \\
Nx & $46(12.1 \%)$ & $16(18.2 \%)$ & 0.129 & -1.515 to 15.875 & 2.307 \\
\hline Resection margin & & & & & \\
R1 & $32(8.4 \%)$ & $5(5.7 \%)$ & 0.398 & -4.644 to 7.272 & 0.715 \\
R0 & $274(72.3 \%)$ & $73(83.0 \%)$ & 0.039 & 0.573 to 18.668 & 4.275 \\
Rx & $73(19.3 \%)$ & $10(11.4 \%)$ & 0.081 & -1.181 to 14.540 & 3.038 \\
\hline PDR - pancreatoduodenal resections; VR - vascular resections; P- p-value; $95 \% \mathrm{Cl}-$ Confidence interval (95\%); $\chi^{2}$ test - Chi-squared test.
\end{tabular}

\section{Discussion}

PMVA invasion per se is not a contraindication for surgery $(13,18,32-34)$. One of the main aims of the intervention is achievement of clear resection margins $(16,35,36)$. When performed by a skilled surgical team, VR becomes a routine procedure for radical removal of the tumour (37-39). The decision for vascular resection is important and depends primarily on perioperative assessment and patient selection. However, there is no recommendation consensus yet for either initial resection or neoadjuvant treatment approach. In most cases with BRPC, we have performed upfront surgery. Neoadjuvant ChT followed by resection was performed in single patients only, but their limited number does not allow for a conclusive judgement of treatment efficacy yet.

Many studies do not demonstrate survival differences in patients with PDR compared to those with VR $(3,16,18,23,32-34,40-47)$. Other authors report worse survival in vascular resections attributable to more aggressive tumour characteristics (48-51). The results from our study show a significant difference in survival in favour of PDR - 26.9 months vs. 19.3 months in VR (Table 1). Nevertheless, $1^{-}, 3^{-}$and 5-year survival rates were not statistically significant $(\mathrm{p}=0.128,0.501$ and 0.105 respectively). A similar correlation in 5-year survival rates has been reported by Siriwardana as far back as in 2006 (52). On the other hand, 30-day mortality in the VR group was considerably higher compared with 
the PDR group $(p=0.0003)$. Similar results have also been reported in a recent metaanalysis by Peng (53). Survival rates comparison in PDR, VR and PP shows significantly lower survival in palliative procedures compared with venous resections $(\mathrm{p}<0.05$, Graph 1). This provides grounds for the conclusion that performance of VR in borderline resectable tumours is a justified procedure aiming at better survival in patients who would otherwise be deemed inoperable. This relationship has also been established by other authors over the years $(16,44,47,54)$.

In Table 2 are listed the clinically relevant postoperative complications, graded according to Clavien-Dindo (55) and ISGPS (56) classifications. There was no significant difference in Grades IIIa, IIIb and IV complications $(p=0.774)$. Similar correlations of postoperative complications have also been found in a number of other studies (11-13,18,27,32$34,42,43,47,57,58)$. On the other hand, the rates of postoperative bleeding and reoperations were significantly higher in the VR group ( $\mathrm{p}=0.026$ and $\mathrm{p}=0.017$ respectively).
These two parameters are also independent prognostic factors for worse survival $(p<0.05$, Graphs. 2 and 3). The incidence of septic complications in vascular resections was also higher $(p=0.004)$, probably due to the large wound area and trauma associated with such surgical volume. There was no significant difference between the two groups in the incidence of POPF $(p=0.168)$ or postoperative biliary fistula $(\mathrm{POBF}, \mathrm{p}=1)$. The increased rate of $\mathrm{POBF}$ in vascular resections demonstrated in a meta-analysis by Peng has led to speculations about a possible hepatoduodenal ligament blood flow disturbance in the course of extended surgery (53). Although many series report similar postoperative complications in PDR compared to VR, some other authors have demonstrated higher complications rates in vascular resections (49-51,59).

The observed incidence of blood transfusions in VR (44.3\%) was much higher and markedly significant than that in standard procedures $(19.8 \%, p<0.0001)$. This could also be attributed to the higher incidence of reoperations in vascular resections. One of the most common

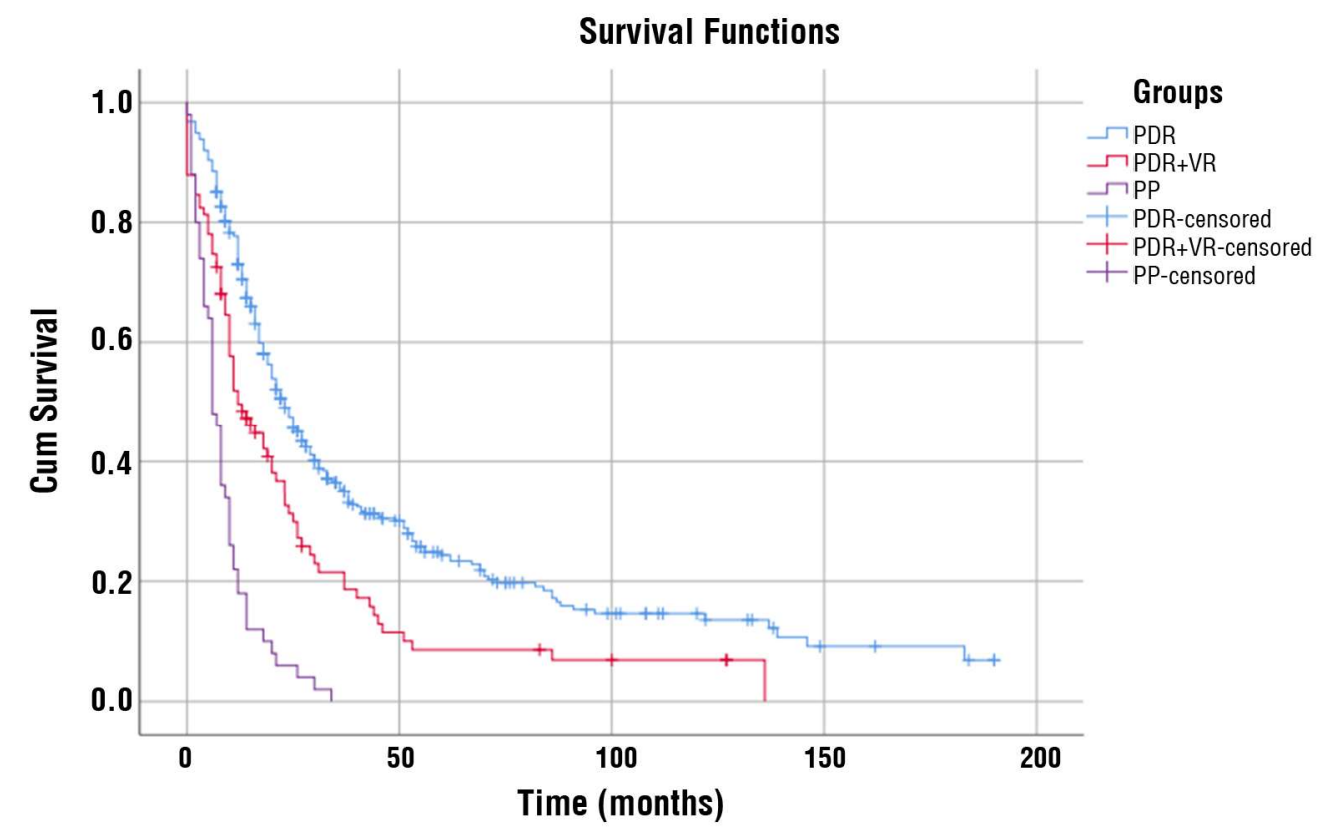

Graph 1. The comparison of long-term survival in PDR, VR and PP groups

Kaplan-Maier survival comparison in PDR, VR and PP showed statistically significant differences between all three groups $(p<0.05)$ 


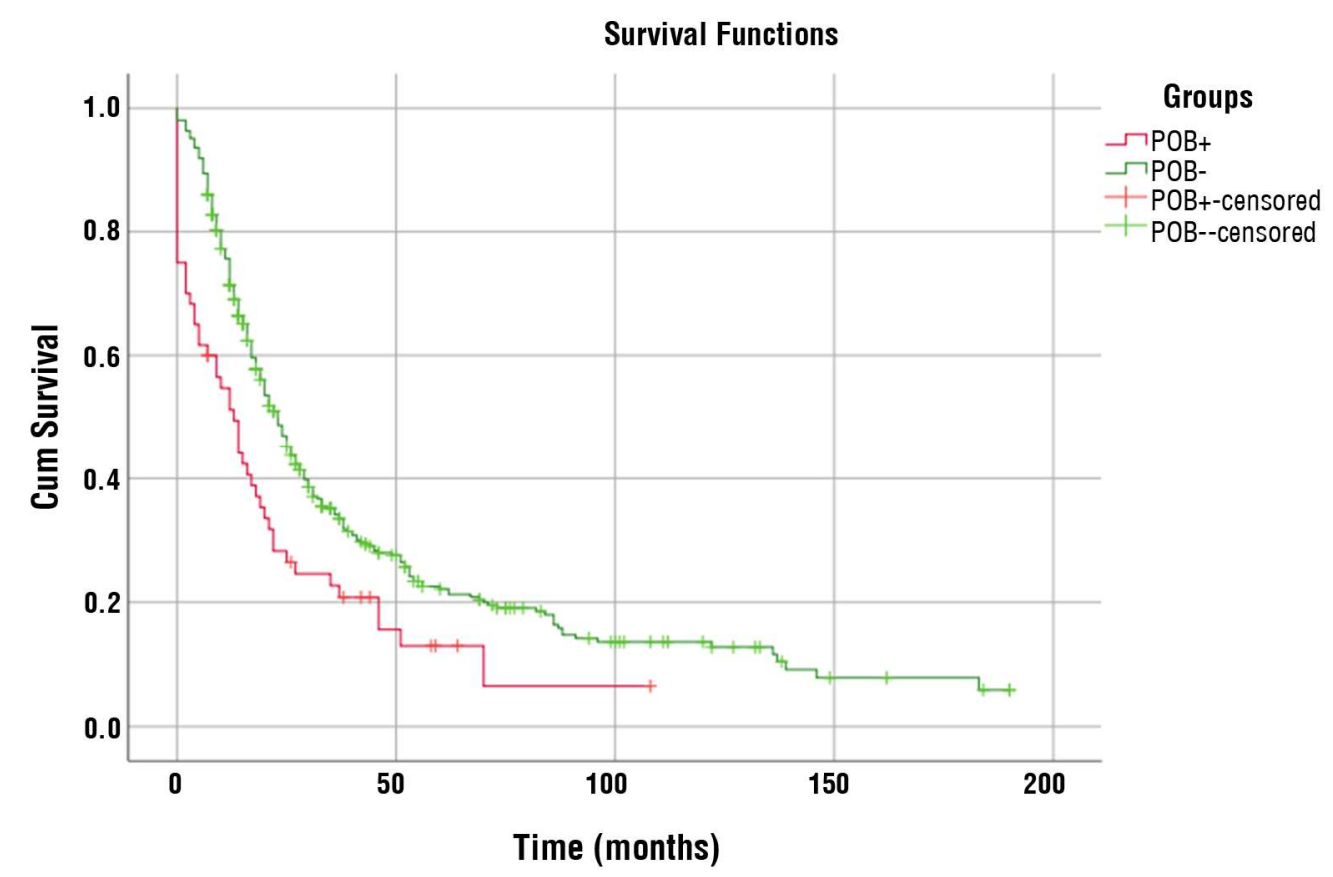

Graph 2. The comparison of survival in postoperative bleeding

Comparison of survival in cases with $(\mathrm{POB}+)$ and without (POB-) postoperative bleeding - statistically significant $(\mathrm{p}<0.05)$

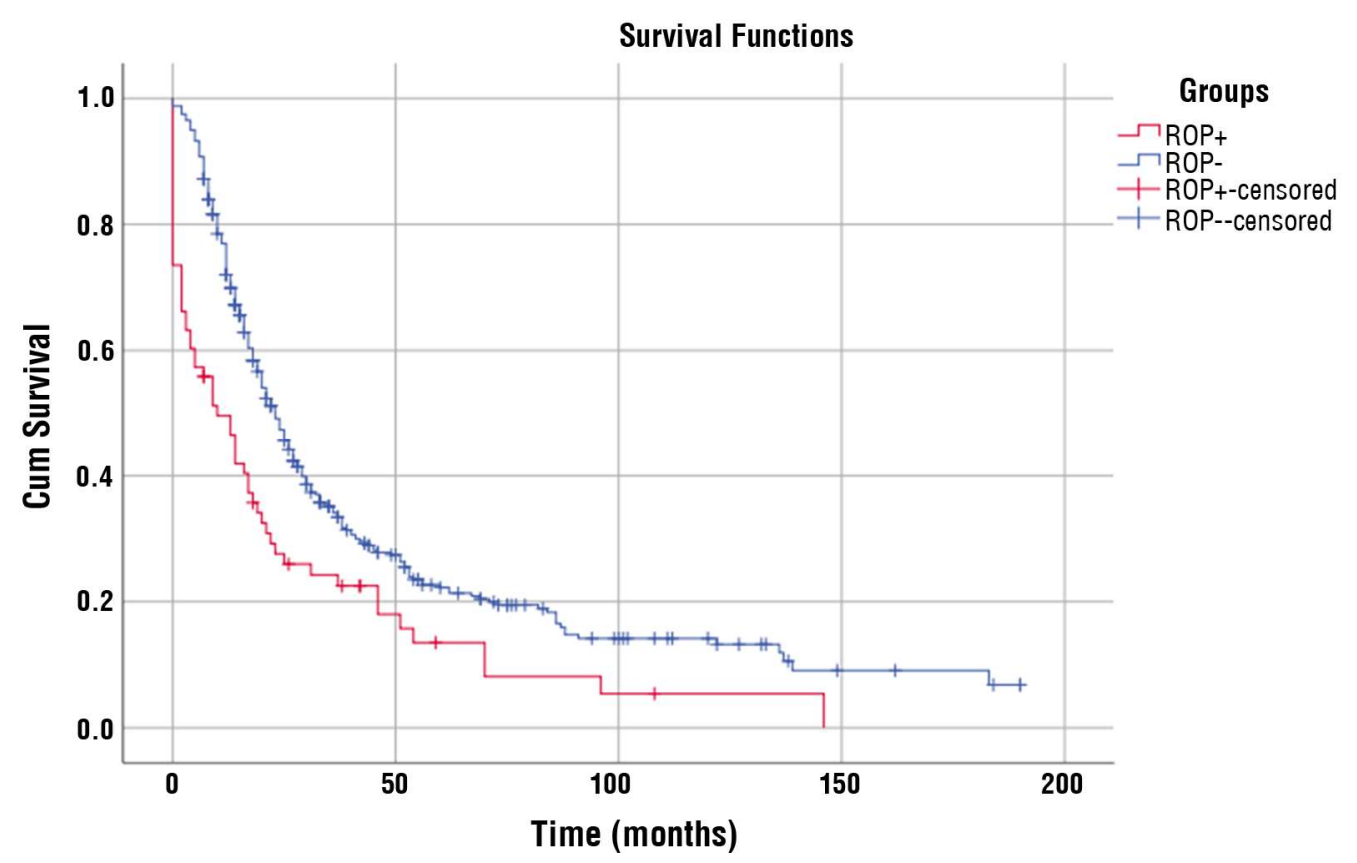

Graph 3. The comparison of survival in reoperation

Comparison of survival in cases with (ROP+) and without (ROP-) reoperations - statistically significant $(\mathrm{p}<0.05)$.

series complications reported by Ravikumar in 2014 were blood transfusion requirements during the early postoperative period (47).

Regarding the type of surgical procedures performed in the two groups, pylorus-preserving resections were more frequent in the PDR group $(\mathrm{p}=0.001)$, while in the VR group were performed more total pancreatectomies $(p<0.0001)$. The 
latter is attributed to the more extensive resections in vascular procedures.

The average hospital stay was half a day longer in VR compared to PDR (16.6 vs. 17.1), without statistical significance $(p=0.576)$. Such correlation has been reported by other authors as well (47). The meta-analysis by Peng (53) demonstrates longer hospital stay in vascular resections.

The average tumour size was $16 \mathrm{~mm}$ larger in VR, however far below the significance level $(\mathrm{p}=0.193$, Table 3). Ravikumar has found that the average size of blastomas observed in vascular resections is insignificantly larger than those in standard procedures (47). VR opponents on the other hand argue that because of vascular invasion BRPC are generally larger and have a worse prognosis $(27,60-62)$. According to Peng, the average size of tumours in vascular resections is larger compared to those in standard pancreatoduodenal procedures (53). Furthermore, some series demonstrate that the lack of significant histological differences between the two groups shows that vascular invasion is rather due to topographic factors than to the histological aggressiveness of the tumour $(50,63,64)$.

No significant differences were found in the lymphovascular and perineural invasion status $(p>0.05)$. A certain correlation in the degree of tumour differentiation was observed, with G1 carcinomas being more common in PDR $(p=0.045)$ compared to a higher percentage of G3 tumours in VR $(p=0.045)$. No statistically significant differences were found about moderately differentiated blastomas. Michalski reports longer survival rates after vascular resection in patients with $\mathrm{G} 1$ and G2 tumours compared to patients with G3 neoplasms (65). The same statistically significant correlation was found in our study ( $\mathrm{p}=0.006$, Graph 4).

The percentage of R0-resections observed in vascular procedures was higher (83\%) and statistically significant compared to PDR $(72.3 \%, \mathrm{p}=0.039)$. There were no significant differences between the two groups regarding the rate of $\mathrm{R} 1$-resections $(\mathrm{p}=0.398)$. According to publications by Peng (53) and Ravikumar (47), R1-resections prevail in the VR group. In

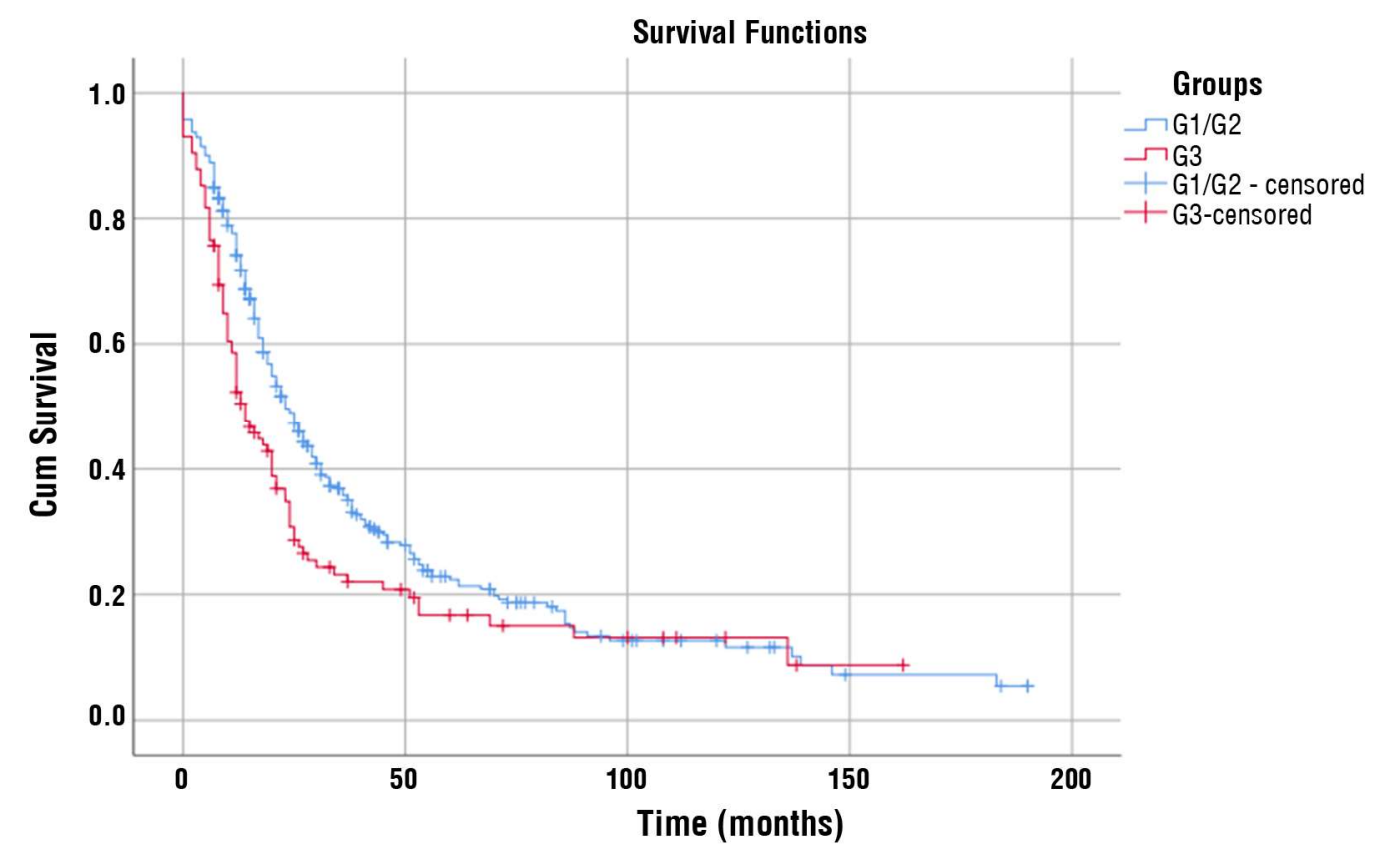

Graph 4. The comparison of survival at degrees of differentiation

Longer survival rates after VR in G1/G2 group compared to patients with $G 3$ ( $p=0.006)$ 


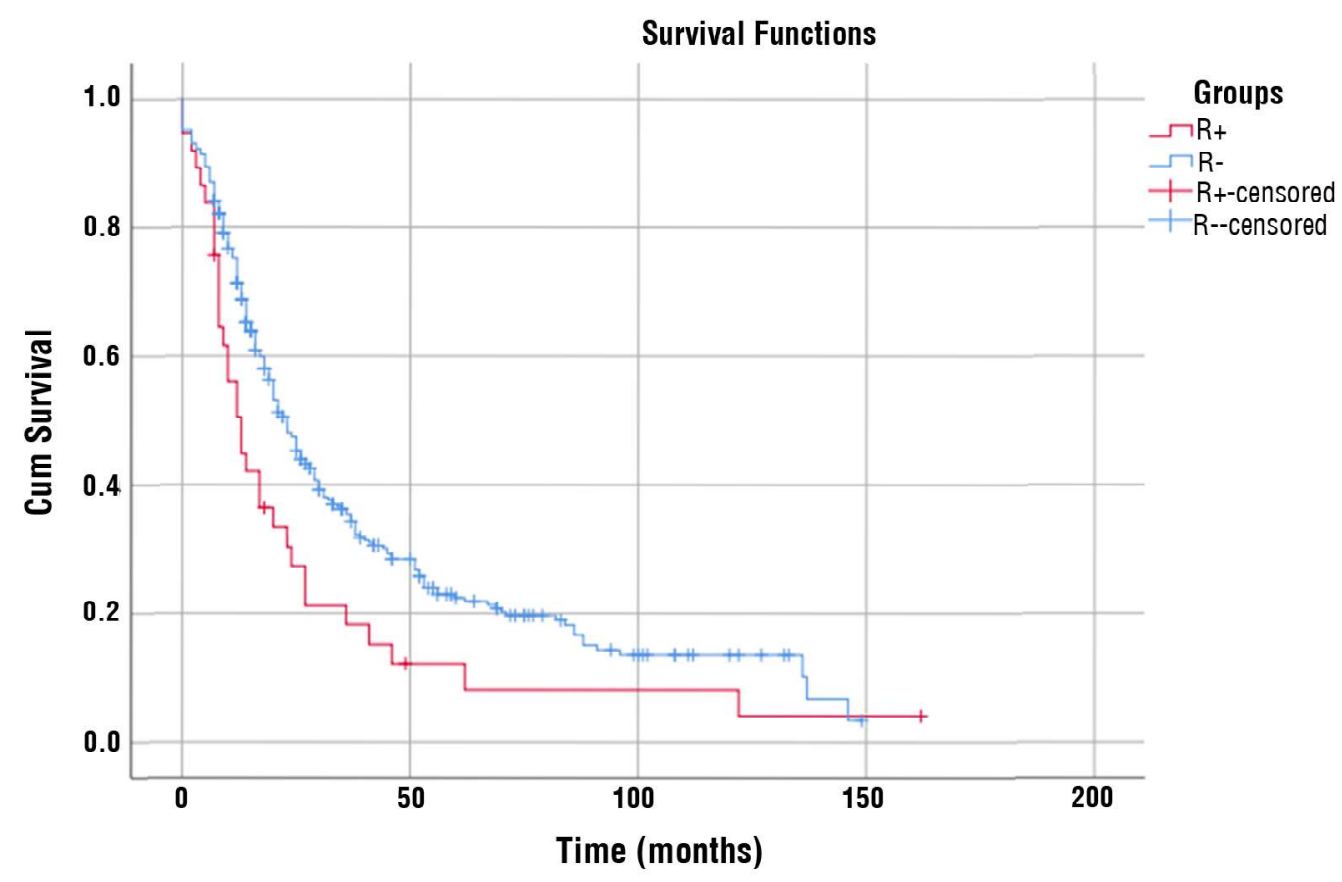

Graph 5. The comparison of survival in resection margins

R0-resections are associated with better survival compared to R1 group $(p=0.011)$

addition, R0-resections are associated with better survival compared to R1-resections $(\mathrm{p}=0.011$, Graph 5). Carrere confirms that achievement of an R0-resection is a major prognostic factor, therefore venous involvement is not a contraindication for pancreaticoduodenal resection (66). Other series have also demonstrated that R0-resection is a favourable prognostic marker for longer survival (67-70). In contrast, the results from several studies performed during the past decade show that R1-resection status has no impact on longterm survival $(18,27,41,71)$.
PDR are associated with higher onset incidence of jaundice manifestations $(p=0.02)$ while vascular resections are characterized by higher onset manifestations of pain $(\mathrm{p}=0.005)$. This is explained by the tumour localization and the presence of either bile duct infiltration or involvement of retroperitoneal nerve plexuses and PMVA.

In Table 4 are listed the performed vascular resections. In addition to 88 venous resections, were performed 5 arterial and 6 inferior vena cava resections. One of the most common localizations was the portal vein

Table 4. Vascular resections

\begin{tabular}{|c|c|c|c|c|}
\hline \multirow[t]{2}{*}{ Type of resection } & \multirow[t]{2}{*}{$\begin{array}{l}\text { Tangential } \\
n=41(46.6 \%)\end{array}$} & \multicolumn{2}{|c|}{$\begin{array}{c}\text { Segmenta } \\
n=47(53.4 \%)\end{array}$} & \multirow[t]{2}{*}{ Total } \\
\hline & & $\begin{array}{l}\text { End-to-End } \\
n=36(40.9 \%)\end{array}$ & $\begin{array}{c}\text { Graft } \\
n=11(12.5 \%)\end{array}$ & \\
\hline PV & $25(28.4 \%)$ & 20 (22.7\%) & $5(5.7 \%)$ & $50(56.8 \%)$ \\
\hline SMV & 14 (15.9\%) & $9(10.2 \%)$ & $3(3.4 \%)$ & $26(29.5 \%)$ \\
\hline Confluence & $2(2.3 \%)$ & 7 (8.0\%) & $3(3.4 \%)$ & $12(13.7 \%)$ \\
\hline IVC & & & & 6 \\
\hline SMA & & & & 5 \\
\hline
\end{tabular}

PV - portal vein; SMV - superior mesenteric vein; IVC - inferior vena cava; SMA - superior mesenteric artery 
$(\mathrm{n}=50,56.8 \%)$, followed by the SMV $(\mathrm{n}=26$, 29.5\%). 41 tangential (46.6\%) and 47 segmen- $^{-}$ tal resections (53.4\%) were performed, 36 of which were done with end-to-end vascular anastomosis (40.9\%), and 11 with grafts (12.5\%, 7 synthetic prostheses and 4 autologous grafts). No statistical relationship between the type of resection and the documented postoperative complications was observed even in cases with prosthetic reconstructions $(p>0.05)$. In their series Hackert, Schneider and Büchler point out that the use of such synthetic grafts may lead to higher incidence of complications as infection or anastomotic leakage (19). The specific situation of a synthetic graft in combination with a pancreatic fistula must be regarded as a high-risk constellation for postoperative haemorrhage or difficult to treat long-lasting graft infection.

According to different authors, histologically confirmed vascular invasion is observed in $21 \%$ to $70 \%$ of patients $(80,86-88)$. In our series, histological venous infiltration $(\mathrm{V}+)$ was present in $43.2 \% \quad(n=38)$ of patients with performed vascular resection, but absent (V-) in $26.1 \%(n=23)$ of patients. The histological status of the remaining $30.7 \%(n=27)$ was classified as $\mathrm{Vx}$, i.e. their vascular status could not be determined due to pathological limiting factors. There were no significant differences in the survival rates between patients with $\mathrm{V}+$ and V- status ( $\mathrm{p}=0.581$, Graph 6). The same outcomes have been reported by a number of other authors $(11,16,18,27)$. On the other hand, Nakagohri points out that negative vascular infiltration status (V-) is associated with better survival (75). Mierke has reported important findings of higher incidence of development of metachronous liver metastases consistent with histologically confirmed venous infiltration $(\mathrm{V}+)(76)$. The median survival in those patients was 11.9 months vs. 16.1 months in patients without vascular infiltration. The median survival in our study was 18 months in patients from the $\mathrm{V}$ - group and 16 months in the $V+$ group ( $>>0.05)$.

The limited number of inferior vena cava $(n=6)$ and SMA resections $(n=5)$ did not provide conclusive evidence of the benefits and

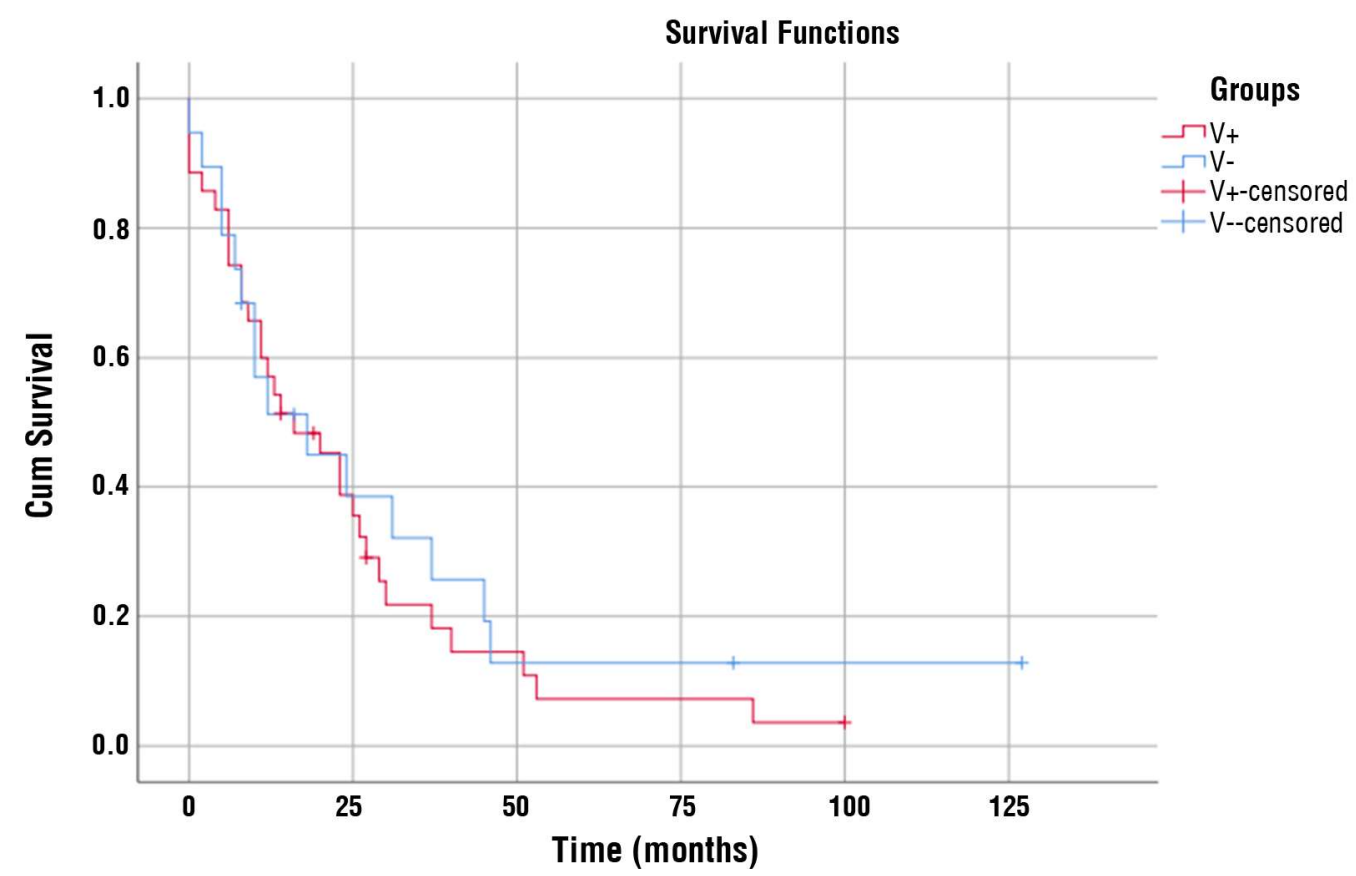

Graph 6. The comparison of survival regarding the presence of venous invasion No significant differences in the survival rates regarding the venous status $(p=0.581)$ 
disadvantages of this type of vascular procedures. Mollberg has reported higher incidence of complications $(53.6 \%)$ and perioperative mortality $(11.8 \%)$ in patients who underwent arterial resection as compared with standard PDR procedures (26). In addition, arterial resections are associated with worse 1-year and median survival (21). Nevertheless, there is also an opinion that arterial resections can be carried out safety in experienced hands but at this stage cannot be recommended as a standard procedure (13). Del Chiaro have even demonstrated an advantage of arterial resections in terms of survival comparable to that in palliative procedures (77).

In conclusion, median survival rates observed in VR were lower than that in PDR. Nevertheless, 1-, 3- and 5-year survival rates were fully comparable statistically. Among patients with vascular resections was observed significant perioperative mortality. The comparison of long-term outcomes in PDR, VR and PP showed worse survival in vascular resections relative to standard procedures, yet significantly higher than that in palliative procedures. The total percentage of clinically relevant complications in the two groups was fully comparable, except for higher incidence of postoperative bleeding and reoperations in VR, both being independent prognostic factors for survival. In consequence, the percentage of blood transfusions in vascular resections was much higher. The average size of tumours in VR was slightly larger compared with that in standard procedures but without statistically significant differences. On the other hand, the percentage of poorly differentiated tumours in vascular resections was significantly higher. R0-resections, associated with better longterm outcomes than R1-resections, were achieved more frequently in the VR group. The most common clinical manifestation of disease onset in the PDR group was jaundice, while in vascular resection the most common symptom was pain. There was no evidence that the presence or absence of venous infiltration in the group with vascular resections has significant impact on survival.
One of the limitations of our study is its retrospective design. In addition, long-term postoperative follow-up for quality-of-life assessment was not practically possible in all patients Another shortcoming was the impossibility to determine resection margins, vascular and perineural invasion status in a certain percentage of histologically examined specimen. In addition, for determination of resection margins were used different criteria.

\section{Conclusion}

Vascular resections in pancreatic cancer remain a great challenge for all surgeons. The decision for their performance should not be impulsive but based on strict patient selection after careful benefit-risk assessment. Compared with palliative procedures vascular resections are associated with better survival outcomes almost comparable to those in standard procedures. The performed analysis shows that pancreatoduodenal procedures in combination with venous resections are reliable and safe but only when performed by surgeons with long-term experience in high-volume centres of excellence.

\section{Conflicts of Interest and Source of Funding}

No funding to declare.

\section{Ethics Approval}

Ethical approval was waived by the local Ethics Committee of Military Medical Academy - Sofia (Bulgaria) in view of the retrospective nature of the study and all the procedures being performed were part of the routine care.

\section{References}

1. Neuzillet C, Gaujoux S, Williet N, Bachet JB, Bauguion L, Colson Durand L, et al. Pancreatic cancer: French clinical practice guidelines for diagnosis, treatment and follow-up (SNFGE, FFCD, GERCOR, UNICANCER, SFCD, SFED, SFRO, ACHBT, AFC). Dig Liver Dis. 2018;50(12):1257-1271.

2. Rahib L, Smith BD, Aizenberg R, Rosenzweig AB, Fleshman JM, Matrisian LM. Projecting cancer incidence and deaths to 2030: The unexpected burden of thyroid, liver, and pancreas cancers in the united states. Cancer Res. 2014;74(11):2913-21. 
3. Al-Haddad M, Martin JK, Nguyen J, Pungpapong S, Raimondo M, Woodward $\mathrm{T}$, et al. Vascular resection and reconstruction for pancreatic malignancy: A single center survival study. J Gastrointest Surg. 2007;11(9): 1168-74.

4. Butturini G, Stocken DD, Wente MN, Jeekel H, Klinkenbijl JHG, Bakkevold $\mathrm{KE}$, et al. Influence of resection margins and treatment on survival in patients with pancreatic cancer: Meta-analysis of randomized controlled trials. Arch Surg. 2008;143(1):75-83; discussion 83.

5. Bockhorn M, Uzunoglu FG, Adham M, Imrie C, Milicevic M, Sandberg AA, et al. Borderline resectable pancreatic cancer: a consensus statement by the International Study Group of Pancreatic Surgery (ISGPS). Surgery. 2014; 155(6):977-88

6. Illuminati G, Carboni F, Lorusso R, D'Urso A, Ceccanei G, Papaspyropoulos $V$, et al. Results of a pancreatectomy with a limited venous resection for pancreatic cancer. Surg Today. 2008;38(6):517-23.

7. Neoptolemos JP, Russell RCG, Bramhall S, Theis B. Low mortality following resection for pancreatic and periampullary tumours in 1026 patients: UK survey of specialist pancreatic units. UK Pancreatic Cancer Group. Br J Surg. 1997;84(10):1370-6.

8. Soriano A, Castells A, Ayuso C, Ayuso JR, De Caralt MT, Ginès MÀ, et al. Preoperative staging and tumor resectability assessment of pancreatic cancer: prospective study comparing endoscopic ultrasonography, helical computed tomography, magnetic resonance imaging, and angiography. Am J Gastroenterol. 2004:99(3):492-501.

9. Beltrame V, Gruppo M, Pedrazzoli S, Merigliano S, Pastorelli D, Sperti C. Mesenteric-portal vein resection during pancreatectomy for pancreatic cancer. Gastroenterol Res Pract. 2015;2015:659730.

10. Hartwig W, Vollmer CM, Fingerhut A, Yeo CJ, Neoptolemos JP, Adham M, et al. Extended pancreatectomy in pancreatic ductal adenocarcinoma: Definition and consensus of the International Study Group for Pancreatic Surgery (ISGPS). Surgery. 2014;156(1):1-14.

11. Yekebas EF, Bogoevski D, Cataldegirmen G, Kunze C, Marx A, Vashist YK, et al. En bloc vascular resection for locally advanced pancreatic malignancies infiltrating major blood vessels: Perioperative outcome and long-term survival in 136 patients. Ann Surg. 2008;247(2):300-9.

12. Wang C, Wu H, Xiong J, Zhou F, Tao J, Liu T, et al. Pancreaticoduodenectomy with vascular resection for local advanced pancreatic head cancer: A single center retrospective study. J Gastrointest Surg. 2008;12(12): 2183-90.

13. Luketina RR, Hackert T, Büchler MW. Vascular resection in pancreatic cancer. Indian J Surg. 2015;77(5):381-6.

14. Batool S, Malik AA, Bari H, ul Islam I, Hanif F. Vascular resection and reconstruction in pancreatic tumours. J Coll Physicians Surg Pak. 2018;28(6): 485-487.

15. Del Chiaro M, Segersvärd R, Rangelova E, Coppola A, Scandavini CM, Ansorge $C$, et al. Cattel-Braasch maneuver combined with artery first approach (CBAF) for superior mesenteric-portal vein (SMPV) resection during pancreatectomy. J Gastrointest Surg. 2015;19(12):2264-8.

16. Tseng JF, Raut CP, Lee JE, Pisters PWT, Vauthey JN, Abdalla EK, et al. Pancreaticoduodenectomy with vascular resection: Margin status and survival duration. J Gastrointest Surg. 2004;8(8):935-49; discussion 949-50.

17. Hackert T, Ulrich A, Büchler MW. Borderline resectable pancreatic cancer. Cancer Lett. 2016;375(2):231-237.

18. Müller SA, Hartel M, Mehrabi A, Welsch T, Martin DJ, Hinz U, et al. Vascular resection in pancreatic cancer surgery: survival determinants. J Gastrointest Surg. 2009;13(4):784-92.

19. Hackert T, Schneider L, Büchler MW. Current state of vascular resections in pancreatic cancer surgery. Gastroenterol Res Pract. 2015;2015:120207.

20. Dua MM, Tran TB, Klausner J, Hwa KJ, Poultsides GA, Norton JA, et al. Pancreatectomy with vein reconstruction: technique matters. HPB (Oxford). 2015;17(9):824-31.

21. Glebova NO, Hicks CW, Piazza KM, Abularrage CJ, Cameron AM, Schulick $\mathrm{RD}$, et al. Technical risk factors for portal vein reconstruction thrombosis in pancreatic resection. J Vasc Surg. 2015;62(2):424-33.

22. Settmacher U, Langrehr JM, Husmann I, Eisele R, Bahra M, Heise M, et al. Reconstruction of visceral arteries with homografts in excision of the pancreas. Chirurg. 2004;75(12):1199-206. German
23. Martin RCG, Scoggins CR, Egnatashvili V, Staley CA, McMasters KM, Kooby DA. Arterial and venous resection for pancreatic adenocarcinoma operative and long-term outcomes. Arch Surg. 2009;144(2):154-9.

24. Jegatheeswaran S, Baltatzis M, Jamdar S, Siriwardena AK. Superior mesenteric artery (SMA) resection during pancreatectomy for malignant disease of the pancreas: a systematic review. HPB (Oxford). 2017;19(6): 483-490.

25. Horton KM, Fishman EK. Multidetector CT angiography of pancreatic carcinoma: Part I, evaluation of arterial involvement. AJR Am J Roentgenol. 2002;178(4):827-31.

26. Mollberg N, Rahbari NN, Koch M, Hartwig W, Hoeger Y, Büchler MW, et al. Arterial resection during pancreatectomy for pancreatic cancer: A systematic review and meta-analysis. Ann Surg. 2011;254(6):882-93.

27. Ouaissi M, Hubert C, Verhelst R, Astarci P, Sempoux C, Jouret-Mourin A, et al. Vascular reconstruction during pancreatoduodenectomy for ductal adenocarcinoma of the pancreas improves resectability but does not achieve cure. World J Surg. 2010;34(11):2648-61.

28. Bockhorn M, Burdelski C, Bogoevski D, Sgourakis G, Yekebas EF, Izbicki JR. Arterial en bloc resection for pancreatic carcinoma. Br J Surg. 2011; 98(1):86-92. Epub 2010 Oct 25

29. Hartwig W, Hackert T, Hinz U, Hassenpflug M, Strobel O, Büchler MW, et al. Multivisceral resection for pancreatic malignancies: Risk-analysis and longterm outcome. Ann Surg. 2009;250(1):81-7.

30. Bachellier P, Rosso E, Lucescu I, Oussoultzoglou E, Tracey J, Pessaux P, et al. Is the need for an arterial resection a contraindication to pancreatic resection for locally advanced pancreatic adenocarcinoma? a case-matched controlled study. J Surg Oncol. 2011;103(1):75-84.

31. Weitz J, Rahbari N, Koch M, Büchler MW. The "artery first" approach for resection of pancreatic head cancer. J Am Coll Surg. 2010;210(2):e1-4. Epub 2009 Dec 3.

32. Fuhrman GM, Leach SD, Staley CA, Cusack JC, Charnsangavej C, Cleary $\mathrm{KR}$, et al. Rationale for en bloc vein resection in the treatment of pancreatic adenocarcinoma adherent to the superior mesenteric-portal vein confluence. Ann Surg. 1996;223(2):154-62.

33. Harrison LE, Klimstra DS, Brennan MF. Isolated portal vein involvement in pancreatic adenocarcinoma: A contraindication for resection? Ann Surg. 1996;224(3):342-7; discussion 347-9

34. Kim PTW, Wei AC, Atenafu EG, Cavallucci D, Cleary SP, Moulton CA, et al. Planned versus unplanned portal vein resections during pancreaticoduodenectomy for adenocarcinoma. Br J Surg. 2013;100(10):1349-56.

35. Evans DB, Farnell MB, Lillemoe KD, Vollmer C, Strasberg SM, Schulick RD. Surgical treatment of resectable and borderline resectable pancreas cancer: Expert consensus statement. Ann Surg Oncol. 2009;16(7):1736-44.

36. Tseng JF, Tamm EP, Lee JE, Pisters PWT, Evans DB. Venous resection in pancreatic cancer surgery. Best Pract Res Clin Gastroenterol. 2006;20(2): 349-64.

37. Hackert T, Büchler MW, Werner J. Current state of surgical management of pancreatic cancer. Cancers (Basel). 2011;3(1):1253-73.

38. Seufferlein T, Porzner M, Becker T, Budach V, Ceyhan G, Esposito I, et al. S3-guideline exocrine pancreatic cancer. Z Gastroenterol. 2013; 51(12):1395-440. German

39. Seufferlein T, Bachet JB, Van cutsem E, Rougier P. Pancreatic adenocarcinoma: ESMO-ESDO clinical practice guidelines for diagnosis, treatment and follow-up. Ann Oncol. 2012:23 Suppl 7:vii33-40.

40. Murakami Y, Satoi S, Motoi F, Sho M, Kawai M, Matsumoto I, et al. Portal or superior mesenteric vein resection in pancreatoduodenectomy for pancreatic head carcinoma. Br J Surg. 2015;102(7):837-46.

41. Jahromi AH, Jafarimehr E, Dabbous HM, Chu Q, D'Agostino H, Shi R, et al. Curative resection of pancreatic adenocarcinoma with major venous resection/repair is safe procedure but will not improve survival. JOP. 2014;15(5):433-41.

42. Riediger H, Makowiec F, Fischer E, Adam U, Hopt UT. Postoperative Morbidity and Long-term Survival After Pancreaticoduodenectomy With Superior Mesenterico-Portal Vein Resection. J Gastrointest Surg. 2006; 10(8):1106-15

43. Hartel M, Niedergethmann M, Farag-Soliman M, Sturm JW, Richter A, Trede $M$, et al. Benefit of venous resection for ductal adenocarcinoma of the 
pancreatic head. Eur J Surg. 2002;168(12):707-12

44. Boggi U, Del Chiaro M, Croce C, Vistoli F, Signori S, Moretto C, et al. Prognostic implications of tumor invasion or adhesion to peripancreatic vessels in resected pancreatic cancer. Surgery. 2009;146(5):869-81.

45. Chu CK, Farnell MB, Nguyen JH, Stauffer JA, Kooby DA, Sclabas GM, et al. Prosthetic graft reconstruction after portal vein resection in pancreaticoduodenectomy: A multicenter analysis. J Am Coll Surg. 2010;211(3): 316-24.

46. Howard TJ, Villanustre N, Moore SA, Dewitt J, Leblanc J, Maglinte D, et al. Efficacy of venous reconstruction in patients with adenocarcinoma of the pancreatic head. J Gastro Surg. 2003;7(8):1089-95.

47. Ravikumar R, Sabin C, Hilal MA, Bramhall S, White S, Wigmore S, et al Portal vein resection in borderline resectable pancreatic cancer: A United Kingdom multicenter study. J Am Coll Surg. 2014;218(3):401-11.

48. Wang F, Gill AJ, Neale M, Puttaswamy V, Gananadha S, Pavlakis N, et al. Adverse tumor biology associated with mesenterico-portal vein resection influences survival in patients with pancreatic ductal adenocarcinoma. Ann Surg Oncol. 2014;21(6):1937-47.

49. Castleberry AW, White RR, De La Fuente SG, Clary BM, Blazer DG, McCann $R L$, et al. The impact of vascular resection on early postoperative outcomes after pancreaticoduodenectomy: An analysis of the American college of surgeons national surgical quality improvement program database. Ann Surg Oncol. 2012;19(13):4068-77.

50. Banz VM, Croagh D, Coldham C, Tanière P, Buckels J, Isaac J, et al. Factors influencing outcome in patients undergoing portal vein resection for adenocarcinoma of the pancreas. Eur J Surg Oncol. 2012;38(1):72-9. Epub 2011 Nov 3.

51. Kantor O, Talamonti MS, Stocker SJ, Wang CH, Winchester DJ, Bentrem DJ, et al. A graded evaluation of outcomes following pancreaticoduodenectomy with major vascular resection in pancreatic cancer. J Gastrointest Surg. 2016;20(2):284-92

52. Siriwardana HPP, Siriwardena AK. Systematic review of outcome of synchronous portal-superior mesenteric vein resection during pancreatectomy for cancer. Br J Surg. 2006:93(6):662-73

53. Peng C, Zhou D, Meng L, Cao Y, Zhang H, Pan Z, et al. The value of combined vein resection in pancreaticoduodenectomy for pancreatic head carcinoma: A meta-Analysis. BMC Surg. 2019;19(1):84.

54. Gong Y, Zhang L, He T, Ding J, Zhang H, Chen G, et al. Pancreaticoduodenectomy Combined with Vascular Resection and Reconstruction for Patients with Locally Advanced Pancreatic Cancer: A Multicenter, Retrospective Analysis. PLoS One. 2013;8(8):e70340

55. Clavien PA, Barkun J, De Oliveira ML, Vauthey JN, Dindo D, Schulick RD, et al. The clavien-dindo classification of surgical complications: Five-year experience. Ann Surg. 2009;250(2):187-96

56. Dusch N, Lietzmann A, Barthels F, Niedergethmann M, Rückert F, Wilhelm TJ. International Study Group of Pancreatic Surgery Definitions for Postpancreatectomy Complications: Applicability at a High-Volume Center. Scand J Surg. 2017;106(3):216-223

57. Kulemann B, Hoeppner J, Wittel U, Glatz T, Keck T, Wellner UF, et al. Perioperative and long-term outcome after standard pancreaticoduodenectomy, additional portal vein and multivisceral resection for pancreatic head cancer. J Gastrointest Surg. 2015;19(3):438-44.

58. Zhou Y, Zhang Z, Liu Y, Li B, Xu D. Pancreatectomy combined with superior mesenteric vein-portal vein resection for pancreatic cancer: A metaanalysis. World J Surg. 2012;36(4):884-91.

59. Worni M, Castleberry AW, Clary BM, Gloor B, Carvalho E, Jacobs DO, et al. Concomitant vascular reconstruction during pancreatectomy for malignant disease: A propensity score-adjusted, population-based trend analysis involving 10206 patients. JAMA Surg. 2013;148(4):331-8.

60. Allema JH, Reinders ME, Van Gulik TM, Van Leeuwen DJ, De Wit LT, Verbeek PCM, et al. Portal vein resection in patients undergoing pancreatoduodenectomy for carcinoma of the pancreatic head. Br J Surg. 1994;
81(11):1642-6

61. Launois B, Franci J, Bardaxoglou E, Ramee MP, Paul JL, Malledant Y, et al. Total pancreatectomy for ductal adenocarcinoma of the pancreas with special reference to resection of the portal vein and multicentric cancer. World J Surg. 1993;17(1):122-6; discussion 126-7.

62. Roder JD, Stein HJ, Siewert JR. Carcinoma of the periampullary region: Who benefits from portal vein resection? Am J Surg. 1996;171(1):170-4; discussion 174-5

63. Leach SD, Lee JE, Charnsangavej C, Cleary KR, Lowy AM, Fenoglio CJ, et al. Survival following pancreaticoduodenectomy with resection of the superior mesenteric-portal vein confluence for adenocarcinoma of the pancreatic head. Br J Surg. 1998;85(5):611-7.

64. Pedrazzoli S, DiCarlo V, Dionigi R, Mosca F, Pederzoli P, Pasquali C, et al. Standard versus extended lymphadenectomy associated with pancreatoduodenectomy in the surgical treatment of adenocarcinoma of the head of the pancreas: A multicenter, prospective, randomized study. Ann Surg. 1998; 228(4):508-17.

65. Michalski CW, Kong B, Jäger C, Kloe S, Beier B, Braren R, et al. Outcomes of resections for pancreatic adenocarcinoma with suspected venous involvement: A single center experience. BMC Surg. 2015;15:100

66. Carrère N, Sauvanet A, Goere D, Kianmanesh R, Vullierme MP, Couvelard $A$, et al. Pancreaticoduodenectomy with mesentericoportal vein resection for adenocarcinoma of the pancreatic head. World J Surg. 2006;30(8): 1526-35.

67. Jain S, Sacchi M, Vrachnos P, Lygidakis NJ. Carcinoma of the pancreas with portal vein involvement - Our experience with a modified technique of resection. Hepatogastroenterology. 2005;52(65):1596-600.

68. Wenger FA, Peter F, Zieren J, Steiert A, Jacobi CA, Müller JM. Prognosis factors in carcinoma of the head of the pancreas. Dig Surg. 2000;17(1): 29-35.

69. Schniewind B, Bestmann B, Kurdow R, Tepel J, Henne-Bruns D, Faendrich $F$, et al. Bypass surgery versus palliative pancreaticoduodenectomy in patients with advanced ductal adenocarcinoma of the pancreatic head, with an emphasis on quality of life analyses. Ann Surg Oncol. 2006;13(11): 1403-11.

70. Wagner M, Redaelli C, Lietz M, Seiler CA, Friess H, Büchler MW. Curative resection is the single most important factor determining outcome in patients with pancreatic adenocarcinoma. Br J Surg. 2004;91(5):586-94.

71. Flis V, Potrc S, Kobilica N, Ivanecz A. Pancreaticoduodenectomy for ductal adenocarcinoma of the pancreatic head with venous resection. Radiol Oncol. 2016:50(3):321-8.

72. Arslan A, Buanes T, Geitung JT. Pancreatic carcinoma: MR, MR angiography and dynamic helical CT in the evaluation of vascular invasion. Eur $\mathrm{J}$ Radiol. 2001;38(2):151-9.

73. Megibow AJ, Zhou XH, Rotterdam H, Francis IR, Zerhouni EA, Balfe DM, et al. Pancreatic adenocarcinoma: CT versus MR imaging in the evaluation of resectability - Report of the radiology diagnostic oncology group. Radiology. 1995;195(2):327-32

74. Aktekin A, Küçük M, Odabasi M, Muftuoglu T, Gürleyik G, Özkara S, et al. The importance of invasion and resection of superior mesenteric and portal veins in adenocarcinoma of the pancreas. Hepatogastroenterology. 2013;60(125):1194-8

75. Nakagohri T, Kinoshita T, Konishi M, Inoue K, Takahashi S. Survival benefits of portal vein resection for pancreatic cancer. Am J Surg. 2003; 186(2):149-53

76. Mierke F, Hempel S, Distler M, Aust DE, Saeger HD, Weitz J, et al. Impact of Portal Vein Involvement from Pancreatic Cancer on Metastatic Pattern After Surgical Resection. Ann Surg Oncol. 2016;23(Suppl 5):730-736.

77. Del Chiaro M, Rangelova E, Halimi A, Ateeb Z, Scandavini C, Valente R, et al. Pancreatectomy with arterial resection is superior to palliation in patients with borderline resectable or locally advanced pancreatic cancer. HPB (Oxford). 2019;21(2):219-225. Epub 2018 Aug 6. 